\title{
ONLINE FOREIGN LANGUAGE INTERACTION: MOVING FROM THE PERIPHERY TO THE CORE OF FOREIGN LANGUAGE EDUCATION
}

\author{
Robert O'Dowd \\ University of León, Spain
}

\begin{abstract}
The last number of years have seen increased popularity of online activity in foreign language activity thanks to the emergence of user-friendly Web 2.0 technologies and the widespread availability of broadband internet access in schools and homes. However, I would argue that despite these developments, online foreign language interaction remains relatively a peripheral 'add-on' activity in most educational institutions which is not considered an integral part of curricular activity and which do not form a significant part of high stakes assessment procedures. Against this background, it can become increasingly difficult for educators to convince learners of the value of their online work over long periods. With this in mind, this paper will argue that a new phase of research into online foreign language education is necessary, which will examine how this activity can be successfully integrated into foreign language curricula and how it can be more closely linked to assessment tools and procedures. I will also consider the challenges which educators often encounter when they seek to implement online learning activity in their institutions.
\end{abstract}

Key-words: online intercultural exchange, telecollaboration, normalisation, integration 


\section{Introduction}

Probably the two most significant developments in the area of online collaborative learning in recent years have been the fall in cost of computer hardware and the emergence of Web 2.0 online technologies. The fall in the price of information and communication technologies has meant that schools have been able to provide more classes with computers, laptops, interactive whiteboards at relatively little expense. Meanwhile, the increased popularity of Web 2.0 tools such as blogs, Wikis and podcasts has meant that teachers can engage their learners in online interaction and publishing without a great deal of technical knowledge or ability. The main outcome of these two developments is that the technical impediments for engaging learners in online education have been significantly reduced.

But does this mean that educators at university and secondary school level are actually involving their learners in online learning activity more than before? In this paper I will focus on online intercultural interaction and exchange in the area of foreign language education and I will argue that although there appear to be fewer technical impediments for integrating online interaction into foreign language classrooms, there continue to be numerous pedagogical hurdles which need to be surmounted before activities such as online intercultural exchange projects can be successfully integrated into foreign language programmes. However, before looking at the issue of integration and normalisation of online foreign language exchange, I would like to provide a brief overview of what form online foreign language exchange has actually taken in classrooms, to identify what have been its contributions to foreign language education and, finally, to examine what are the limitations and weaknesses of current models.

\section{Changing Perceptions of Online Intercultural Exchange}

Traditionally, online intercultural exchange projects in foreign language education has involved the use of [text-based] online communication tools to bring together language learners in two different countries to learn the others' language and culture. Also referred to as telecollaboration (O'Dowd and Ritter, 2006) and in France as EIEGL (Échanges Interculturels Exolingues en Groupe en Lingue) (Audras and Chanier, 2008), online intercultural exchange has generally taken one of two forms or models. In the e-tandem model (O'Rourke, 2007), two native speakers of different languages communicate together with the aim of learning the other's language. These exchanges are based on the principles of autonomy and reciprocity and the responsibility for a successful exchange rests mainly with the learner. In these exchanges, learners are expected to provide feedback on their partners' content and on their foreign language performance. In this sense, tandem partners in many ways take on the role of a peer-tutors who correct their partners' errors and propose alternative formulations in the target language. Messages are meant to be written $50 \%$ in the target language and 50\% in the mother tongue, thereby providing each partner with an opportunity to practise their target language and, at the same time, to provide their partner with authentic input in their target language. This extract from a message written from an American student to her Spanish partner is a typical example of a e-tandem message:

\section{Hey Pablo!}

It was great to receive your letter. I was so happy to see that you responded to my questions. Thank you. Your responses were very informative and definitely showed me that family life in Spain was not all I'd expected it to be ... 
Your English is very good. There are only a few suggestions that I have to correct it. Some of your sentences are too long, and would make more sense if you separated them into two or three sentences instead. For example, "My parents are not divorced in Spain there are very few cases of divorced" could be rewritten as "My parents are not divorced. In Spain there are very few cases of divorce." Your letter was great and made sense despite these things. Good work.

Las fiestas en the ciudad de Nueva York son muy locas y emocionantes. Voy a las discotecas con mis amigas los jueves, los viernes, o los sabados. Vamos a los bars tambien. Nosotros volvemos a nos salons de dormitorio a las cuatro de la manana. Queremos bailar a las discotecas. ...

No sabo mucho de Espana. Sabo que hay un museo de Guggenheim en Bilbao y sabo que hay muchos castillos bonitos. Que sabes de los Estados Unidos? Como es la fiesta en Espana?

A second, alternative model of online intercultural exchange could be described as Blended Intercultural Telecollaboration. This model involves international class-to-class partnerships in which projects and tasks are developed by the partner teachers in the collaborating institutions. Generally, the exchange is strongly integrated into the students' contact classes where online interaction and publications are prepared, analyzed and reflected upon with the guidance of the teacher. The emphasis of the exchanges is on developing cultural awareness and other aspects of intercultural communicative competence. For this reason, common activities include collaborative research projects comparing both cultures and the analysis of 'parallel cultural texts'. For example, French and American students are often engaged in comparative studies of the film 'Three men and a baby' with French original (Furstenberg; Levet; English and Maillet, 2001).

Incarnations of both of these models have been used extensively in foreign language education programmes over the past two decades and the analysis of the outcomes of online foreign language interaction and exchange has become an important area of study in CALL (Computer Assisted Language Learning) journals and publications. Much of my own work in this area has highlighted the difficulties and limitations of attempting to develop learners' target language proficiency and intercultural competence though online interaction, however I would argue that this activity has made some very important contributions to foreign language education. I will now look briefly at what I consider these contributions to have been.

Firstly, engaging learners in online intercultural exchange has helped many teachers and authors to shift the focus of foreign language education from 'language learning' to 'language and culture learning' as the role of cultural awareness and different cultural perspectives is often highlighted in online intercultural collaboration and exchange. Secondly, interacting with native speakers of the target language has meant that learners now have much greater access to 'authentic' use of the target language and are less dependent on textbooks as the source of language input. Thirdly, online exchange has facilitated a greater connection between 'classroom' and 'fieldwork' in foreign language education as learners are now able to engage in 'semi-authentic' interaction with members of the target culture while still benefiting from the guidance and support of their tutors and classmates. Finally, and perhaps most significantly, by being required to write and speak with distant partners about their local culture, learners are made aware of the relativity of many of their cultural beliefs and perspectives to a much greater extent than if they were interacting with classmates and their local teacher.

Despite these significant contributions to foreign language education, there has been a growing level of criticism with traditional approaches to telecollaboration in recent years in the literature and in the classroom. Firstly, many educators have highlighted the organisational complexity of these exchanges and the difficulties which many teachers find in 
trying to dedicate time to the organisation of an exchange while attending to their other duties and obligations. Ware \& Warschauer, for example, suggest that the type of learning which telecollaboration involves can often be at odds with the institutional demands within which teachers are working:

(...) classroom teachers (...) are under pressure to raise test scores, and most thus shy away from creative project-based instruction in order to concentrate on more narrowly focused interventions related to state examination material (2008:231).

Secondly, although the emphasis in online exchange is often on the development of intercultural awareness, many teachers have found that engaging learners in short periods of virtual contact with members of other cultures can actually serve to confirm stereotypes and increase a negative image of the other culture. The literature is full of examples of this, but I present here a case in point from one of my own Spanish-American exchanges. At the end of the exchange one of my Spanish students submitted an essay based on 5 months intensive interaction with her American partner:

The exchange with American students has been very important for me. It has been very interesting as well because it has helped me to prove that Americans don't care about human beings.

There are two further lines of criticism which are worthy of mention here although I cannot now go into them in great detail here to limitations of space. Firstly, there has been a growing criticism of the underlying belief in the research approaches to online intercultural exchange that members of different cultures use different genres and cultural communication styles in their online intercultural interactions. Goodfellow and Lamy, for example, warn that "...the assumption that a coherent 'genre' or 'style' is characteristic of national cohorts is rarely interrogated (2009: 6)." In other words, the authors question whether it is possible to speak about something which can be called 'French communicative style' and whether it is not a little over-simplistic to describe one monolithic cultural communicative style clashing or causing misunderstandings with another.

Finally there is also the question of authenticity in class to class partnerships. The authors Hanna and de Nooy have pointed out that in class to class telecollaboration

[i]nteraction is restricted to communication with other learners, a situation that is safe and reassuring for beginners and younger learners, but somewhat limiting for more advanced and adult learners, who need practice in venturing beyond the classroom (2009: 88).

The authors propose that it is more authentic and more advantageous to engage learners in interaction in authentic L2 discussion forums such as those related to L2 newspaper and magazine publications. For example, they report on studies of their own learners of French as a foreign language who participated in the discussion forums of French magazines such as Nouvel Observateur.

\section{The Challenge of Normalisation}

This brings me to what I currently consider the main challenge for online intercultural exchange in foreign language education. After having studied this area in some detail for many years (O'Dowd, 2006; 2007; O'Dowd and Ritter, 2006) I am concerned that telecollaboration continues to be seen as an 'add-on' activity which essentially depends on 'pioneering' teachers and highly motivated students and is not considered an integrated or 'normalised' part of study programmes and syllabi at university level. What is meant by 'normalised' in this context? Stephen Bax defines the normalisation of Computer Assisted Language Learning in the following way: 
when computers... are used every day by language students and teachers as an integral part of every lesson, like a pen or a book...without fear or inhibition, and equally without an exaggerated respect for what they can do. They will not be the centre of any lesson, but they will play a part in almost all... They will go almost unnoticed (2003:23).

Similarly, I would argue that if online intercultural exchanges are to become a long-term part of foreign language integration, they need to be seen as an integral part of classroom activity and language programmes without being seen as an extra or supplementary activity and without the unfounded expectations that they will have magical transformative effects on students' linguistic skills and intercultural awareness. In order to establish to what extent this is the case in university level foreign language education around Europe, I developed an interview protocol for university level language instructors who had used online exchanges in their classes and carried out a series of asynchronous interviews with these instructors using email over a two month period. Participants answered an opening set of questions and then, when deemed appropriate, were asked to expand on their answers and provide examples of what they meant in further email correspondence. This protocol was based on the factors in the normalisation of online technologies in foreign language education by Chambers and Bax (2006). The main questions put to the participants were the following:

1. Does your institution provide easy access to up-to-date computer laboratories or provide online technologies (e.g. laptop +beamer, interactive whiteboards) in your standard classrooms?

2. Does your institution provide sufficient technical support and back-up for using online activities in classes?

3. Does your institution provide pedagogical and technical training for staff members in how to use online activities (such as online intercultural exchange) in classes?

4. Are participation in online intercultural exchange projects and the development of online literacies explicitly mentioned in course syllabi in your institution?

5. In general, do you feel that your teaching colleagues consider online intercultural interaction and exchange as important and relevant activities for your students? What are their reactions to you engaging your students in online exchange?

6. Do you find that your students find online interaction and exchange as relevant and important for their learning?

7. What aspects of your students' online activity do you assess when they take part in online exchanges?

- Levels of Participation (e.g. no. of posts written)?

- The level of their writing/speaking in the L2?

- Their ability to interact

- Their electronic literacies (e.g. ability to produce a blog)?

- Their Intercultural Competence (skills, attitudes, cultural awareness)?

- Anything else?....

8. Finally, how do you assess their online exchanges?

- Proof of participation? (e.g. print-outs of their interaction)

- Products of interaction (blogs, websites, essays)?

- Reflection on learning (portfolios, diaries)?

The interviews were carried out with approximately 70 foreign language instructors working at university institutions around Europe who had carried out online intercultural exchanges. Analysis of the collected data is still ongoing but at the moment the following points appear to be generally representative of the state of online exchange in foreign language programmes around Europe.

Firstly, it appears that while instructors have good levels of access to online technologies in their classrooms and receive sufficient technical support for the use of technology, there is 
very little 'pedagogical support' available for colleagues who are interested in learning how to integrate online activities such as telecollaboration into their classes. One respondent commented that "...the training addresses technical issues rather than pedagogical issues", while another explained that "[w]e have a tech support person but he is strictly with us for hardware problems or internal network problems".

Secondly, many respondents observed that while their colleagues saw online intercultural exchange as generally something positive, very few demonstrated any interest in getting involved themselves in such activities as "...the cost-benefit ratio is negative for them [colleagues]. In other words, they realise these exchanges are relevant for the students but it takes too much effort to organise it and I think they wouldn't introduce it in their teaching." Due to this fact, it appears that telecollaboration remains the reserve of highly motivated pioneering teachers who are particularly convinced of the benefits of this activity and who are probably engaged in research related to its outcomes.

Many of the respondents also explained that it was very difficult to integrate exchanges into their syllabi due to the lack of reliability of international partners. As they were unsure whether they would have a particular partner class the following year, they were unwilling to mention the exchange in their programmes and to award significant amounts of marks or credit for participation in the exchange. Some representative comments reflecting this problem can be seen here:

1) [The exchange is...] not in course syllabi, because not everybody can participate. We have many students and participation depends on the quantity of native students willing to participate at the partner institutions.

2) ...I never know whether they [the exchanges] are going to be on or not the following year so I don't include them just in case they are not possible one year.

Finally, the study also reveals a rather problematic approach to evaluation and the awarding of credit to students for participating in online exchange. In general, it would appear that a very small amount of students' final grade is awarded for participating in online exchanges. One respondent commented that "...in the recent two exchanges ... we've only had a tiny fraction of their mark available to us. It was given basically on commitment and participation." While another reported that "...the students only get informal feedback, no grades". In my opinion this can have very problematic consequences for the normalisation of this activity. If students do not receive sufficient recognition in the form of marks or course credit then it will be difficult to motivate them to participate and invest time and effort in carrying our projects with their distant peers. So, with this in mind, if educators and institutions recognise the value of these exchanges, then this recognition needs to be evident in course evaluation.

\section{Conclusion}

To summarise, I attempted to offer in this paper a brief overview of different approaches to online intercultural exchange which have been dominant in third level foreign language education for the past two decades. I looked briefly at some of the contributions which this activity has made to foreign language teaching but I also underlined the weaknesses and limitations of these models which have been discussed in greater detail in the recent literature. The initial findings of my survey on the normalisation of online intercultural exchange also paint a rather bleak picture of the extent to which telecollaboration is being fully integrated into foreign language programmes. A lack of stability in project partners, the lack of support from colleagues and the difficulties in including online exchanges in course syllabi and course evaluation schemes would seem to suggest that telecollaboration is doomed to remain on the 
periphery of foreign language teaching and that its potential will only be exploited by teachers and students who are willing to take it on as an 'add-on' activity apart from traditional skillsbased language activities. Of course, the danger with this 'add-on' approach is that both teachers and students are likely to eventually tire of the extra effort and work which they involve. I believe that this final quotation from one of the respondents in my survey is quite representative of this:

...none of my projects have been the main focus of my classes, so students still see a "standard" curriculum occurring alongside the telecollaboration. Of course, from my perspective, having done 5 different telecollaborations, I feel now that they are not suitable as "on-the-side" projects because there is no time to really bring students' attention to the communication taking place and the language being shared. All of my projects felt rushed. It was frustrating, though I will say there were also good things that came of all of them.

The challenge, of course, is for researchers and educators to look for ways of making the normalisation of online intercultural exchange a more seamless and fluid process. For example, I imagine that greater European integration in education through the Bolonia process may, perhaps, facilitate the development of more stable partnerships among European classrooms. This and other ways to supporting the integration of online exchange will be investigated more in the light of greater analysis of the outcomes of the survey reported here.

\section{Bibliography}

BAX S., 2003, "CALL—past, present and future”. System, Vol 31 (1), 13-28.

CHAMBERS A., BAX S., 2006, "Making CALL work: Towards normalisation". System, Vol. 34 (4), 465-479.

FURSTENBERG G., LEVET S., ENGLISH K., MAILLET K., 2001, "Giving a virtual voice to the silent language of culture: The Culture Project". Language Learning \& Technology, 5 (1), 55-102. Retrieved 17 August, 2005: http://llt.msu.edu/vol5num1/furstenberg/default.html

GOODFELLOW R. and LAMY M.-N., 2009, "Introduction: a Frame for the Discussion of Learning Cultures". In: Goodfellow, Robin and Lamy, Marie-Noelle eds. Learning Cultures in Online Education. Continuum Studies in Education. London: Continuum Books, 1-14.

HANNA B., DE NOOY J., 2009, Learning language and culture via public internet discussion forums. New York: Palgrave Macmillan.

LEVY M., STOCKWELL G., 2006, CALL Dimensions. Options and Issues in Computerassisted Language Learning. Mahwah, NJ: Lawrence Erlbaum.

O'DOWD R., 2006, Telecollaboration and the Development of Intercultural Communicative Competence. Berlin: Langenscheidt.

O'DOWD R. (ed.), 2007, Online Intercultural Exchange: An Introduction for Foreign Language Teachers. Clevedon: Multilingual Matters.

O'DOWD R., RITTER M., 2006, “Understanding and Working with 'Failed Communication' in Telecollaborative Exchanges." CALICO Journal, 23, 623-642.

WARSCHAUER M., WARE M., 2008, "Learning, change, and power: Competing discourses of technology and literacy". In J. Coiro, M., Knobel, C. Lankshear, D. J. Leu (eds.) Handbook of research on new literacies, New York: Lawrence Erlbaum Associates, 215-240. 
Develotte C., Mangenot F., Nissen E. (2009, coord.) Actes du colloque Epal 2009 (Echanger pour apprendre en ligne : conception, instrumentation, interactions, multimodalité), université Stendhal - Grenoble 3, 5-7 juin 2009.

\section{Notice biographique}

Robert O'Dowd (robert.odowd@unileon.es) teaches EFL and Applied Linguistics in Spain at the University of León. He has a Ph.D. on the use of networked technologies in the foreign language classroom and has published various books and articles in the area. He runs teacher training workshops on various themes such as intercultural learning, online technologies in foreign language education and online intercultural exchange. His current research interests include studying telecollaboration, assessing online foreign language learning and the role of online technologies in foreign language teacher education. His homepage is: http://www3.unileon.es/personal/wwdfmrod/ 